\title{
DIRECTIVES ON COMMUNITY USE OF FACE MASKS DURING COVID-19 PANDEMIC: A COMMENTARY ARTICLE
}

\author{
Anjuran Pemakaian Masker Bagi Masyarakat Selama Pandemi Covid-19: \\ Artikel Komentar
}

\author{
Dilip H Liyanage ${ }^{1}$, *Pamila Sadeeka Adikari², KGRV Pathirathna², WDCU Dias³ \\ ${ }^{1}$ Milton Keynes University Hospital Trust, United Kingdom \\ ${ }^{2}$ Ministry of Health, Sri Lanka \\ 3University of Lincoln, United Kingdom \\ *Correspondence: m19604@pgim.cmb.ac.lk
}

\begin{abstract}
Wearing a universal face mask is recommended by most health authorities during the COVID-19 pandemic. This commentary elaborates directives given in relation to the use of face masks and identify the underlying principles for public health recommendations by the government authorities of Australia, Canada, China, Hong Kong, Singapore, the United Kingdom and the United States of America. Key data were considered from official government websites by a team of healthcare management experts. It was argued that the directives recommended by the governments were based on the principles addressing the different facets of COVID-19 pandemic, population dynamics, resource availability and scarcity, and the fact that how the proposed standard of practices would be translated into compulsory obligations in the community. The principles involved regulations versus voluntary compliance of the population, transmission scenario, protection from sick or asymptomatic people, special needs and vulnerable groups, synergistic versus substitute/alternative, occupational health risk, adverse effects on usage, types of masks which depend on the risk or context, change in use practices depending on demand, scarcity and quality assurance. Recommendations of the use of face masks were found to be heterogeneous and apparently inconstant. Within the dynamic situation of the COVID19 pandemic, the directives on community use of face masks were issued based on certain dominant principles and interplayed between principles that should be deeply explored by the healthcare decision makers.
\end{abstract}

\begin{tabular}{lll}
\hline Received: 25 July 2020 & Accepted: 15 October 2020 & Published: 23 March 2021
\end{tabular}

\section{INTRODUCTION}

Coronavirus (COVID-19) infection was first declared in Wuhan city, China, in December 2019 and became a public health issue drastically. The World Health Organization (WHO), on $30^{\text {th }}$ January, 2020, declared COVID-19 as a Public Health Emergency of International Concern and subsequently as a pandemic on $11^{\text {th }}$ March, 2020. At this juncture, many health officials recommended the community to wear face masks outside, especially where the virus transmission is high and wherever other social distancing measures are difficult to maintain (Zhou, 2020). Masks might help to reduce droplet transmission and risk of infection from symptomatic or asymptomatic patients. Awareness about transmission, gateways of exit and entry and methods of transmission provides a basis for planning appropriate control strategies at the spur of the pandemic (Centers for Disease Control and Prevention, 2012).

WHO recommend adhering to personal protective means such as hand hygiene, respiratory etiquette, social distancing, environmental and travelrelated steps to decline and hinder transmission (World Health Organization, 2020c). The two main paths of 
transmission of the virus are through respiratory droplets and contact according to the current evidence (World Health Organization, 2020e). To minimize the respiratory means of transmission in the latter pandemic, WHO have recommended the use of face masks (World Health Organization, 2020h). In the implementation, different countries have recommended the use of face mask for their communities.

Masks can be categorized as medical/ surgical or non-medical/ community masks, and different types may offer different levels of protection (McMaster University- Health Forum, 2020). A medical face mask is a medical device capping the mouth, nose, and chin defending against the transmission of an infective agent amidst the hospital staff and patients. Non-medical face masks differ from the medical counterpart and include various forms, such as self-made or commercial masks or face covers made of cloth (European Centre for Disease Prevention and Control, 2020). However, even countries that have generally advised such masks for public use should be reserved for health workers or those, particularly at high risk. At this point, to make sure that adequate stocks are reserved and available for health care workers, many health authorities have compelled to recommend and promote community face masks instead of medical masks. However, it is paramount to ensure adequate supply to key workers first to prevent them from acquiring occupational respiratory diseases (World Health Organization, 2020f).

Since the commencement of the COVID-19 pandemic, panic about the use of face masks has become a universal issue in almost all over the world with limited or no evidence (Chan et al., 2020). Different countries have included WHO adapted risk-based use of masks among key workers and the general public (World Economic Forum, 2020; World Health Organization, 2020g). Some countries did not advocate the use of surgical masks but urged to use simple cloth face covers, while many other countries made it obligatory to use face masks in public and inflicted fines for those who did not comply with the recommendation (Al Jazeera, 2020; Cheng, Lam and Leung, 2020; European Centre for Disease Prevention and Control, 2020; Feng et al., 2020).

In the wake of countless days of social and economic quarantine, political leaders and people across the sphere need to re-emerge from COVID-19 driven lockdowns. Academia have to investigate evidence-based strategies to re-emerge from strict social mobilization. The use of community facemasks can be marked as one such major unresolved issue (Chan et al., 2020; European Centre for Disease Prevention and Control, 2020; World Health Organization, 2020b).

In fact, social distancing measures such as lockdowns have been only slowing down the spread of the virus but have not been able to eradicate it. Shutting down of businesses and schools and giving stay-athome instructions give time to the scientists and the academia to develop strategies to strike the virus. Different health authorities mainly recommend social distancing and hand hygiene as essential steps to prevent the spread of the virus in the absence of vaccines and drugs to fight or lessen the severity of the disease (World Health Organization, 2020d).

Several Asian countries perceiv a face mask as a supportive device (The Guardian, 2020b). They even banned people with no face masks or compulsory masks on the streets, especially on public transports and closed public places (Forbes, 2020; The Telegraph, 2020). On the other hand, Europe and other developed countries had different 
sentiments on the compulsory use of face masks (Harries, 2020). They believed masks should be set aside for health care workers, other key workers, and sick people to safeguard other people (Carver and Phillips, 2020; CDC, 2020b). Whether face masks helped in preventing the spread of coronavirus has been a dubious issue among health professionals, especially in need of active pharmacological treatment. There are few unresolved questions under review among many health authorities. The question is how useful community face masks and whether it will protect people and others from the virus (Feng et al., 2020; Leung et al., 2020; Mahase, 2020; World Health Organization, 2020a). Most authorities are afraid to recommend compulsory use of face masks also known as universal masking in the community because it can make the situation worse with false sense security if not used properly.

Evidence on accurate representation on the community use of face masks currently does not exist, or few trials have been conducted or in the pipeline during this COVID-19 pandemic. Nevertheless, the available evidence on the protective effect of face masks in community settings from other randomized trials for other respiratory diseases is also inconclusive. The use of face masks probably providea an insignificant added protective effect when used in combination with other public health measures in a situation where social distancing is not possible (European Centre for Disease Prevention and Control, 2020; Gov.UK Developer docs, 2020; The Guardian, 2020a).

Besides, a considerable controversy has been observed in the recommendations of face masks in different stages of the disease progression in some countries. The decision of policymaking in the health system is a difficult task (Dobrow, Goel and Upshur,
2004), especially a challenging activity in limited-resource settings. In the COVID 19 pandemic, the supply chain of Personal Protective Equipment (PPE) is not aligned with the overwhelming demand. Distorted supply of the PPE for healthcare settings contributes to increased risk of spreading infection among front line workers (Gooding, 2016). On the other hand, relaxing lockdown measures and continuing business activities and recommencing economic activities urge new alternative recommendations of preventing the virus transmission. At this critical point of decision-making processes, policymakers face increasing pressures to ensure effective policy recommendations while maintaining balance among key concerns of policymakers, opinions of consumers and professional bodies and evidence gained from research (Robinson, 1993).

Different principles have been considered by the government authorities in the use of face masks as a public health measure eventhough they haveseveral controversial and unclear states of thoughts. In this blurry situation, several principles are observed to make the background for government directives. The principles have played major role in the policy making process claiming for right decisions for each context. The principles include regulations versus voluntary compliance of the population, transmission scenario, protection from sick or asymptomatic people, special needs and vulnerable groups, synergistic versus substitution/alternative effects, occupational health risks, adverse effects on usage, types of mask depending on the risk or context, change in practices in use depending on demand and scarcity and quality of assurance.

This commentary is based on the directives on the use of face masks to the public as the respective governments of 
Australia, Canada, China, Hongkong, Singapore, the United Kingdom (UK) and the United States of America (USA) have issued during the COVID-19 pandemic. The directives are available online in their government official websites with .gov domains. The data were retrived between the period of $10^{\text {th }}$ May, 2020 to 31st May, 2020. Above countries were selected based on the availability of comprehensive government websites and authors' familiarity. Also, the authors believed the same principles in other developing countries were based on the recommended directives on the use of face masks as the whole world have also been fighting the virus and facing a shortage of supplies in an equal manner. Further, the authors observed more confusion in the directives given due to socio-political reasons and freedom of communication. Thus, that made a great context exploring underlying causes.

\section{DISCUSSION}

The authors observed ten principles in which the directives on the use of face masks were issued by the governments to the community during the COVID-19 pandemic. The key directives and their identified broader themes are listed in Table 1.

Table 1: Directives given to the community by the respective government authorities concerning the use of face masks during the COVID-19 pandemic.

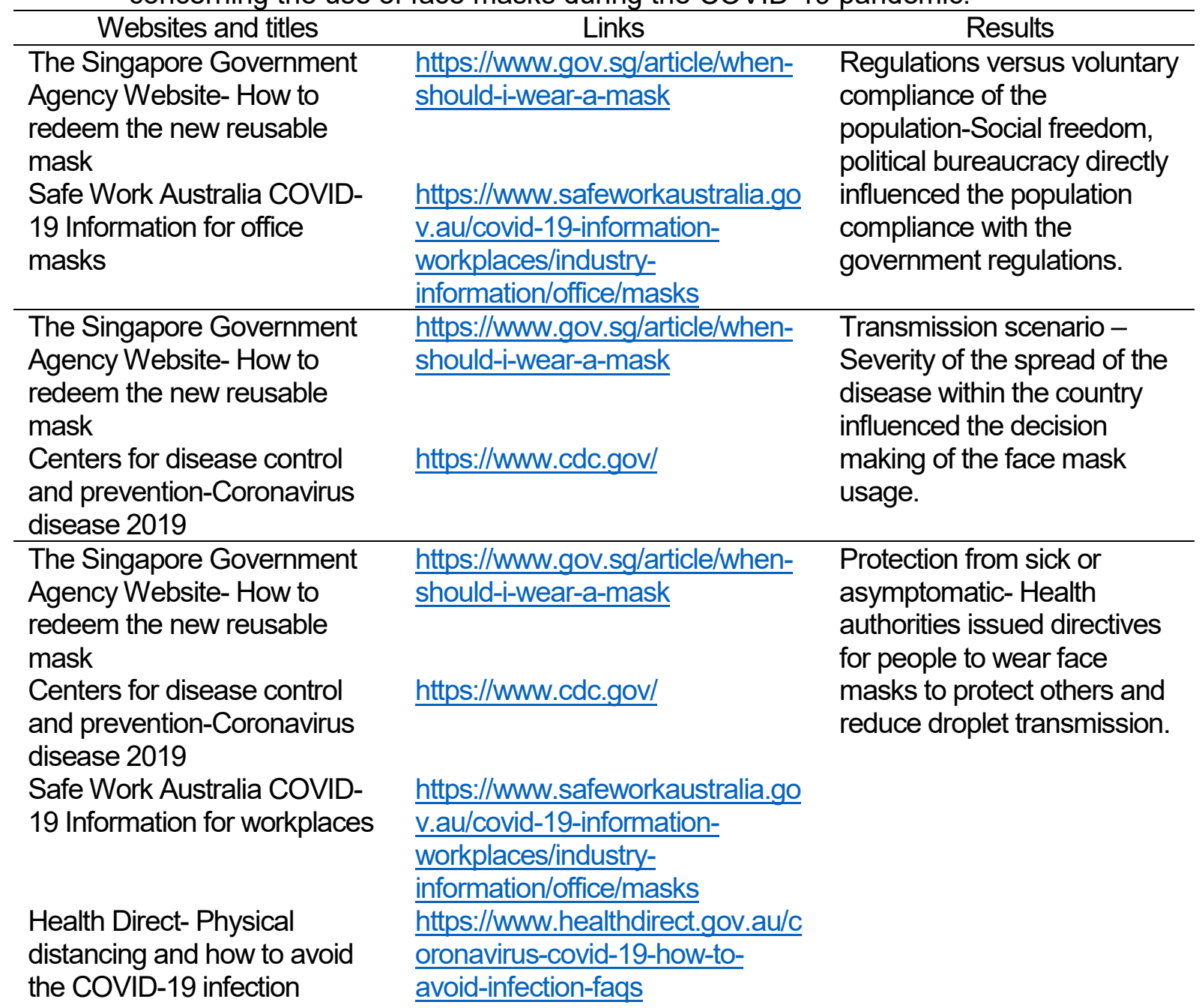


The State Council, Peoples Republic of China, China still encourages healthy people to wear face masks

The Singapore Government Agency Website- How to redeem the new reusable mask

The Singapore Government
Agency Website- How to
redeem the new reusable
mask
The Department of Health,
Hong Kong- Guidelines on
prevention of Coronavirus
disease 2019 (COVID-19) for
the general public.
Centers for disease control
and prevention-Coronavirus
disease 2019
The Australian Government
Department of Health

The UK Government's
COVID-19
recovery strategy, Our plan to
rebuild

https://www.chp.gov.hk/files/pdf/ni d guideline general public en.p $\underline{\mathrm{df}}$

\section{https://www.cdc.gov/}

https://www.health.gov.au/resour ces/publications/coronaviruscovid-19-information-on-the-useof-surgical-masks

https://assets.publishing.service.g ov.uk/government/uploads/syste m/uploads/attachment data/file/8 84760/Our plan to rebuild The UK Government s COVID19 recovery strategy.pdf The Singapore Government Agency Website- How to redeem the new reusable mask

https://www.gov.sg/article/when-
should-i-wear-a-mask

https://www.mom.gov.sg/haze/gui delines-on-protecting-employeesfrom-haze protecting
Occupational health risksGovernment considered the nature of the occupation, linked with the risk of infection. Risk of the adverse events using a face mask during work was also considered. employees from the effect of haze

Safe Work Australia COVID19- Information for workplaces

\footnotetext{
Department of Health

Services, Hong KongGuidelines on prevention of coronavirus disease 2019 (covid-19) for the general public
}

\author{
https://www.safeworkaustralia.go \\ v.au/covid-19-information- \\ workplaces/industry- \\ information/office/masks \\ https://www.chp.gov.hk/files/pdf/ni Adverse effects on usage- \\ d guideline general public en.p \\ $\underline{\mathrm{df}}$
Adverse effect on usage due to underlying medical status and vulnerable physiological status was considered when the governments gave


Centers for disease control and prevention- Coronavirus disease 2019

The official website of the Government of CanadaCoronavirus disease (COVID19) https://www.cdc.gov/

https://www.canada.ca/en.html directives on face mask usage.

\section{Centers for disease control and prevention- Coronavirus disease 2019 \\ The official website of the Government of Canada- Coronavirus disease (COVID- 19),}

Australian Government
Department of Health
Health Direct- Physical
distancing and how to avoid
the COVID-19 infection
National Health Commission
of People's Republic of China-
Tips for choosing and using
masks to prevent novel
coronavirus

https://www.health.gov.au/resour ces/publications/coronaviruscovid-19-information-on-the-useof-surgical-masks https://www.healthdirect.gov.au/c oronavirus-covid-19-how-toavoid-infection-faqs

http://en.nhc.gov.cn/202002/06/c 76398.htm
Types of masks depending on the risk or context Health authorities considered contextual factors which increased the risk of infection and used them to recommend types of face masks in the specific work environment.

\begin{tabular}{|c|c|c|}
\hline $\begin{array}{l}\text { The UK Government's } \\
\text { COVID-19 } \\
\text { recovery strategy, our plan to } \\
\text { rebuild }\end{array}$ & $\begin{array}{l}\text { https://assets.publishing.service.g } \\
\text { ov.uk/government/uploads/syste } \\
\text { m/uploads/attachment data/file/8 } \\
84760 / \text { Our plan to rebuild The } \\
\text { UK Government s COVID- } \\
19 \text { recovery strategy.pdf }\end{array}$ & \\
\hline $\begin{array}{l}\text { Ministry of Health Singapore- } \\
\text { Continued stringent } \\
\text { implementation and } \\
\text { enforcement of circuit breaker } \\
\text { measures }\end{array}$ & $\begin{array}{l}\text { https://www.moh.gov.sg/news- } \\
\text { highlights/details/continued- } \\
\text { stringent-implementation- } \\
\text { enforcement-of-circuit-breaker- } \\
\text { measures }\end{array}$ & \\
\hline $\begin{array}{l}\text { Department of Health } \\
\text { Services, Hong Kong- } \\
\text { Guidelines on prevention of } \\
\text { Coronavirus disease } 2019 \\
\text { (COVID-19) for the general } \\
\text { public }\end{array}$ & $\begin{array}{l}\frac{\text { https://www.chp.gov.hk/files/pdf/ni }}{\text { d guideline general public en.p }} \\
\underline{\text { df }}\end{array}$ & \\
\hline $\begin{array}{l}\text { The State Council, Peoples } \\
\text { Republic of China- China still } \\
\text { encourages healthy people to } \\
\text { wear face masks }\end{array}$ & $\begin{array}{l}\frac{\text { http://english.www.gov.cn/stateco }}{\text { uncil/ministries/202003/24/conten }} \\
\text { t WS5e79ed1ec6d0c201c2cbf57 } \\
\underline{\text { 2.html }}\end{array}$ & \\
\hline $\begin{array}{l}\text { Safe Work Australia COVID- } \\
19 \text { Information for workplaces }\end{array}$ & $\begin{array}{l}\text { https://www.safeworkaustralia.go } \\
\text { v.au/covid-19-information- }\end{array}$ & $\begin{array}{l}\text { Changes in face mask } \\
\text { usage practices depend on }\end{array}$ \\
\hline
\end{tabular}




\begin{tabular}{|c|c|c|}
\hline & $\begin{array}{l}\text { workplaces/industry- } \\
\text { information/office/masks }\end{array}$ & $\begin{array}{l}\text { demand and scarcity.e.g. } \\
\text { recommendation of masks } \\
\text { that have passed shelf life } \\
\text { and do not have any } \\
\text { physical damages were } \\
\text { recommended by the } \\
\text { governments when there } \\
\text { was a shortage. }\end{array}$ \\
\hline $\begin{array}{l}\text { Safe Work Australia COVID- } \\
19 \text { Information for workplaces }\end{array}$ & $\begin{array}{l}\text { https://www.safeworkaustralia.go } \\
\text { v.au/covid-19-information- } \\
\text { workplaces/industry- } \\
\text { information/office/masks }\end{array}$ & $\begin{array}{l}\text { Quality assurance- Defining } \\
\text { the specifications for face } \\
\text { masks, especially in high risk } \\
\text { working environments. }\end{array}$ \\
\hline $\begin{array}{l}\text { Australian Government } \\
\text { Department of Health- } \\
\text { Therapeutic goods } \\
\text { administration, advice on } \\
\text { surgical masks and gowns } \\
\text { during COVID-19. }\end{array}$ & $\begin{array}{l}\text { https://www.tga.gov.au/advice- } \\
\text { surgical-masks-and-gowns- } \\
\underline{\text { during-covid-19 }}\end{array}$ & \\
\hline $\begin{array}{l}\text { National Medical Products } \\
\text { Administration- Regulatory } \\
\text { requirements and standards } \\
\text { for Coronavirus reagent test } \\
\text { kits and protective equipment } \\
\text { in China. }\end{array}$ & $\begin{array}{l}\text { http://english.nmpa.gov.cn/2020- } \\
\underline{\text { 03/30/c 467202.htm }}\end{array}$ & \\
\hline
\end{tabular}

The recommendations of health authorities for the use of face masks showed significant differences. In the process of public health policy, scientific evidence primarily plays a key role. Besides, the context-specific principles such as economic status, attributes of demand and supplies, political willingness, level of population compliance with public health measures, health system infrastructure and social and cultural factors influence to shape up the final output. This commentary explains underlying principles influencing the formation of policy directives concerning the community use of face masks during the COVID 19 pandemic.

\section{Regulations versus voluntary compliance}

Law enforcement versus voluntary compliance as a principle to implement recommendations of the community use of face masks played differently in various settings. Countries such as Singapore which has strict bound public governance systems (Xinghui, 2020) apply a combined approach as risk communication and legislative fine in contrast to that of the UK. While Canada fully depends on voluntary public compliance based on risk communication strategies (Clark et al., 2020). That indirectly implies social freedom, political bureaucracy, level of population compliance which directly influences decision making processes.

\section{Transmission scenario}

Early flexible directives given by the Singapore government changed according to the epidemiological transmission scenario (Government of Singapore, 2020). At the early stages of scenario, the directives were influenced by other principles. However, at the community transmission scenario and the stage in 
which the practice of rigid public health measures is difficult, the directives emphasizes on the community use of face masks (CDC, 2020a; Cheng, Lam and Leung, 2020). That indicates at the worst situations, scientific factors such as epidemiological transmission scenarios play a dominant role in a decision making process.

\section{Protection from sick or asymptomatic people}

Another underlying principle for the directives on the use of face masks is to protect people from sick or asymtomatic patients. Many health authorities have encouraged people to wear face masks to protect others as you can prevent droplet transmission (Government of Singapore, 2020). On the other hand, the use of face masks may reduce the transmission of the virus and protect people being infected by undetected cases. Importantly, this practice will be helpful if vulnerability to infection is high in situations with higher community transmission and less social distancing.

Unless you are suspected of being infected with COVID-19 or caring for a person who is confirmed or suspected, the use of surgical face masks is not recommended due to lack of evidence and sustainable supplies for key workers. In contrast to above, some countries have recommended universal face masking to prevent or reduce community transmission of COVID-19 (CDC, 2020c; The State Council, The People's Republic of China, 2020).

\section{Special need and vulnerable groups}

It is evident that immune deprivation or vulnerability to diseases is considered as an underlying principle for wearing face masks which protect people from being exposed to the virus (European Centre for Disease Prevention and Control, 2020).
Furthermore, CDC and many health authorities recommendthe community, especially for vulnerable and elderly, to wear face masks on public transportation and where social distancing is not possible (CDC, 2020c).

\section{Synergy versus substitution/alternative effects}

Principally, the majority of health authorities emphasize the importance of synergistic effects of using face masks. The use of face masks was further mentioned as not an alternative/substitute to social distancing and other public health measures such as hand hygiene before wearing and after removing a mask (Public Health Agency of Canada, 2020). Authorities need to be causious when giving directives to the public on the use of face masks. Wearing face masks can give a 'false sense of security' over coronavirus unless they do not adhere to the basic public health principles (Australian Government Department of Health, 2020; CDC, 2020a; Centre for Health Protection, 2020; Government of Singapore, 2020).

\section{Occupational health risks}

Some countries have made recommendations not only for health care workers but also for other key workers by considering occupational risks, individual employee's health conditions, and nature of outdoor/indoor work and use of the appropriate masks after the risk assessment. Also, they highlighted the importance of providing suitable masks, training, fit testing, donning, doffing, and even discarding. Employers have been given the freedom to determine or direct employees not to wear masks if permitted based on the health care guidelines or on a case by case basis on certain circumstances (A Singapore Government Agency Website, 2020; Government of Singapore, 2020; Safe Work Australia, 
2020). For non-health workers who are closely associated with COVID-19 patients, special guidelines have been issued in some countries (Safe Work Australia, 2020).

\section{Adverse effects on usage}

Despite recommendations of universal masking, the observation shows that the directives on the use of the face masks are also based on possible adverse effects upon their usage. CDC and many other health authorities said children under two, people who have breathing difficulty, someone who is unconscious and someone who cannot move or took off a mask without help, are warned against harmful effects (CDC, 2020a). For certain employees, masks may experience distress/difficulty in breathing, tiredness, or headache due to increased resistance to breathing or reduction of air inhaled. In such conditions, guidelines recommend employers to consider regular breaks, slow down the pace of work, and encourage hydration to mitigate the adverse effects ( $A$ Singapore Government Agency Website, 2020).

\section{Types of the mask depending on the risk or context}

Another important principle is the risk of infectivity and specific contextual factors such as confinment in closed spaces, probability of close contacts, and the presence of probable infected patients for choosing types of masks. In the low probability settings, the government has recommended the use of cloth face masks in contrast to N-95 masks for hospital staff (CDC, 2020a; Government of Canada, 2020).

\section{Change in practices in usage depending on demand and scarcity}

Overwhelmed demand for PPE, including face masks, has created a shortage and scarcity in most supply chains in the health systems. In a situation where no other alternatives cannot meet with the demand and supply, some health authorities recommend PPE to be used even after the expiration date. Health workers can use them if the straps are intact and have no signs of visible damage (Australian Government Department of Health Therapeutic Goods Administration, 2020).

\section{Quality assurance}

Though most health authorities had issued technical and quality requirements for using medical face masks (Australian Government Department of Health Therapeutic Goods Administration, 2020; National Medical Products Administration, 2020), they failed to issue such requirements for various forms of selfmade or commercial masks or face covers made of cloth or materials such as paper to be used as community masks (Australian Government Department of Health Therapeutic Goods Administration, 2020). Therefore, future authorities should pay attention to these important principles to ensure effective outcomes for the use of face masks.

\section{CONCLUSION}

Recommendations for using face masks by the governments discussed earlier are heterogeneous and inconstant. The contextual factors and expansion of knowledge on COVID -19 have affected those recommendations. Interestingly, the recommendations on the standard practices were seriously affected more by resource availability and feasibility than scientific judgment.

This commentary has presented several principles underlying the directives given by the government in relation to the use of face masks. However, within the 
dynamic context of the ongoing pandemic, it is evident that certain directives dominated based on the contexual requirements. Besides, thare was the simultaneous interplay between several principles influencing the authorities to give the directions. In that case, this article emphasizes that the healthcare decision makers should correctly identify the complex situations and dominant principles before giving recommendations for using face masks to the public.

\section{CONFLICT OF INTEREST}

The authors declared no conflict of interest in this article.

\section{REFERENCES}

A Singapore Government Agency Website (2020) Ending circuit breaker: phased approach to resuming activities safely. Available at: http://www.gov.sg/article/endingcircuit-breaker-phased-approach-toresuming-activities-safely

(Accessed: 2 August 2020).

Al Jazeera (2020) Which countries have made wearing face masks compulsory? Available at: https://www.aljazeera.com/news/202 0/04/countries-wearing-face-maskscompulsory-200423094510867.html.

Australian Government Department of Health (2020) Coronavirus (COVID19), Information on the use of surgical masks. Available at: https://www.health.gov.au/resources /publications/coronavirus-covid-19information-on-the-use-of-surgicalmasks.

Australian Government Department of Health Therapeutic Goods Administration (2020) Advice on surgical masks and gowns during COVID-19, Therapeutic Goods
Administration (TGA). Australian Government Department of Health. Available at: https://www.tga.gov.au/advicesurgical-masks-and-gowns-duringcovid-19 (Accessed: 16 July 2020).

Carver, P. E. and Phillips, J. (2020) 'Novel Coronavirus (COVID-19): What You Need to Know', Workplace Health \& Safety, 68(5), pp. 250-250. doi: $10.1177 / 2165079920914947$.

CDC (2020a) CDC Works 24/7, Centers for Disease Control and Prevention. Available at: https://www.cdc.gov/index.htm (Accessed: 13 July 2020).

CDC (2020b) Coronavirus Disease 2019 (COVID-19) - How to protect yourself and others, Centers for Disease Control and Prevention. Available at: https://www.cdc.gov/coronavirus/201 9-ncov/prevent-gettingsick/prevention.html (Accessed: 16 July 2020).

CDC (2020c) Coronavirus Disease 2019 (COVID-19)- About Cloth Face Coverings, Centers for Disease Control and Prevention. Available at: https://www.cdc.gov/coronavirus/201 9-ncov/prevent-getting-sick/aboutface-coverings.html (Accessed: 13 July 2020).

Centers for Disease Control and Prevention (2012) Principles of Epidemiology, Lesson 1 - Section 10. Available at: https://www.cdc.gov/csels/dsepd/ss1 978/lesson1/section10.html (Accessed: 9 July 2020).

Centre for Health Protection (2020) 'Guidelines on Prevention of Coronavirus Disease 2019 (COVID19) for the General Public'. Available at: https://www.chp.gov.hk/files/pdf/nid_ guideline_general_public_en.pdf. 
Chan, A. L. et al. (2020) To wear or not to wear: WHO's confusing guidance on masks in the covid-19 pandemic, The BMJ. Available at: https://blogs.bmj.com/bmj/2020/03/1 $1 /$ whos-confusing-guidance-maskscovid-19-epidemic/ (Accessed: 13 July 2020).

Cheng, K. K., Lam, T. H. and Leung, C. C. (2020) 'Wearing face masks in the community during the COVID-19 pandemic: altruism and solidarity', The Lancet, p. S0140673620309181. doi: 10.1016/S0140-6736(20)309181.

Clark, C. et al. (2020) 'Predictors of COVID-19 voluntary compliance behaviors: An international investigation', Global Transitions, 2, pp. 76-82. doi: 10.1016/j.glt.2020.06.003.

Dobrow, M. J., Goel, V. and Upshur, R. E. G. (2004) 'Evidence-based health policy: context and utilisation', Social Science \& Medicine, 58(1), pp. 207$217 . \quad$ doi: 10.1016/S02779536(03)00166-7.

European Centre for Disease Prevention and Control (2020) Using face masks in the community - Reducing COVID19 transmission from potentially asymptomatic or pre-symptomatic people through the use of face masks, European Centre for Disease Prevention and Control. Available at: https://www.ecdc.europa.eu/en/publi cations-data/using-face-maskscommunity-reducing-covid-19transmission (Accessed: 16 July 2020).

Feng, S. et al. (2020) 'Rational use of face masks in the COVID-19 pandemic', The Lancet Respiratory Medicine, 8(5), pp. 434-436. doi: 10.1016/S2213-2600(20)30134-X.

Forbes (2020) Paris Bans Daytime Outdoor Exercise As French Cities Consider
Making Face Masks Compulsory. Available at: https://www.forbes.com/sites/alexled som/2020/04/07/france-clampsdownno-outside-sport-before-7pmin-paris-and-compulsory-facemasks-in-largecities/\#6eb057a5157f.

Gooding, E. J. (2016) A mixed methods approach to modeling personal protective equipment supply chains for infectious disease outbreak response. $\mathrm{PhD}$ Thesis. Massachusetts Institute of Technology.

Government of Canada (2020) The official website of the Government of Canada. Available at: https://www.canada.ca/en.html.

Government of Singapore (2020) How to redeem the new reusable mask. Available at: http://www.gov.sg/article/whenshould-i-wear-a-mask (Accessed: 13 July 2020).

Gov.UK Developer docs (2020) 'Wearing facemasks in a community setting: options and evidence'. Available at: https://assets. publishing.service.gov. uk/government/uploads/system/uplo ads/attachment_data/file/890233/s0 150-wearing-facemasks-communitysetting-options-evidence-160420sage26.pdf.

Harries, D. (2020) COVID-19: Europe's mixed mask messaging. Available at: https://newseu.cgtn.com/news/202004-19/COVID-19-Europe-s-mixedmask-messagingPP9R49HpPa/index.html.

Leung, C. et al. (2020) 'Mask wearing to complement social distancing and save lives during COVID-19', Int J Tuberc Lung $D$.

Mahase, E. (2020) 'Covid-19: What is the evidence for cloth masks?', BMJ, p. m1422. doi: 10.1136/bmj.m1422. 
McMaster University- Health Forum (2020) 'COVID-19 Rapid Evidence Profile \#4'. Available at: https://www.mcmasterforum.org/doc s/default-source/covidend/rapidevidence-profiles/covid-19-rep4_non-medicalmasks.pdf?sfvrsn=73bd57d5 2 .

National Medical Products Administration (2020) Regulatory Requirements and Standards for Coronavirus Reagent Test Kits and Protective Equipment in China. Available at: http://english.nmpa.gov.cn/202003/30/c_467202.htm (Accessed: 16 July 2020).

Public Health Agency of Canada (2020) Community-based measures to mitigate the spread of coronavirus disease (COVID-19) in Canada. Available at: https://www.canada.ca/en/publichealth/services/diseases/2019novel-coronavirus-infection/healthprofessionals/public-healthmeasures-mitigate-covid-19.html (Accessed: 17 July 2020).

Robinson, R. (1993) 'The policy context', BMJ (Clinical research ed.), 307(6910), pp. 994-996. doi: 10.1136/bmj.307.6910.994.

Safe Work Australia (2020) Masks. Available at: https://www.safeworkaustralia.gov.a u/covid-19-informationworkplaces/industryinformation/office/masks (Accessed: 16 July 2020).

The Guardian (2020a) Report on face masks' effectiveness for Covid-19 divides scientists. Available at: https://www.theguardian.com/world/ 2020/may/04/scientists-disagreeover-face-masks-effect-on-covid-19.

The Guardian (2020b) To help stop coronavirus, everyone should be wearing face masks. The science is clear. Available at: https://www.theguardian.com/comm entisfree/2020/apr/04/why-wear-amask-may-be-our-best-weapon-tostop-coronavirus.

The State Council, The People's Republic of China (2020) China still encourages healthy people to wear face masks. Available at: http://english.www.gov.cn/statecoun cil/ministries/202003/24/content_WS 5e79ed1ec6d0c201c2cbf572.html (Accessed: 13 July 2020).

The Telegraph (2020) Public should wear face masks, government says. Available at: https://www.telegraph.co.uk/globalhealth/science-anddisease/coronavirus-news-endlockdown-boris-johnson-new-rulesschool/.

World Economic Forum (2020) Why lockdowns can halt the spread of COVID-19, World Economic Forum. Available at: https://www.weforum.org/agenda/20 20/03/why-lockdowns-workepidemics-coronavirus-covid19/ (Accessed: 17 July 2020).

World Health Organization (2020a) 'Interim Guidance- Advice on the use of masks in the context of COVID-19'. Available at: https://www.who.int/publications/i/ite m/advice-on-the-use-of-masks-inthe-community-during-home-careand-in-healthcare-settings-in-thecontext-of-the-novel-coronavirus(2019-ncov)-outbreak.

World Health Organization (2020b) 'Interim guidance- Advice on the use of masks the community, during home care and in health care settings in the context of the novel coronavirus (2019-nCoV) outbreak'. Available at: https://www.who.int/docs/default- 
source/documents/advice-on-theuse-of-masks-2019-ncov.pdf.

World Health Organization (2020c) 'Interim guidance- Overview of public health and social measures in the context of COVID-19'. Available at: https://apps.who.int/iris/bitstream/ha ndle/10665/332115/WHO-2019nCoV-PHSM_Overview-2020.1eng.pdf?sequence $=1$ \&isAllowed=y.

World Health Organization (2020d) 'Interim Recommendation 1 April 2020'. Available at: https://www.who.int/docs/defaultsource/inaugural-who-partnersforum/who-interim-recommendationon-obligatory-hand-hygiene-againsttransmission-of-covid-19.pdf.

World Health Organization (2020e) Modes of transmission of virus causing COVID-19: implications for IPC precaution recommendations. Available at: https://www.who.int/newsroom/commentaries/detail/modes-oftransmission-of-virus-causing-covid19-implications-for-ipc-precautionrecommendations (Accessed: 9 July 2020).

World Health Organization (2020f) 'Strengthening and adjusting public health measures throughout the COVID-19 transition phases'. WHO Regional Offce for Europe. Available at:

https://www.euro.who.int/_data/ass ets/pdf_file/0018/440037/Strength-
AdjustingMeasuresCOVID19transition-phases.pdf.

World Health Organization (2020g) Updated WHO recommendations for international traffic in relation to COVID-19 outbreak. Available at: https://www.who.int/newsroom/articles-detail/updated-whorecommendations-for-internationaltraffic-in-relation-to-covid-19outbreak (Accessed: 17 July 2020).

World Health Organization (2020h) When and how to use masks. Available at: https://www.who.int/emergencies/dis eases/novel-coronavirus2019/advice-for-public/when-andhow-to-use-masks (Accessed: 16 July 2020).

Xinghui, K. (2020) Singapore makes face masks compulsory as virus cases surge to 3,252, South China Morning Post. Available at: https://www.scmp.com/weekasia/healthenvironment/article/3079889/corona virus-singapore-makes-face-maskscompulsory (Accessed: 13 July 2020).

Zhou, W. (2020) The coronavirus prevention handbook: 101 sciencebased tips that could save your life. Available at: https://www.overdrive.com/search?q =76E6C249-9E76-47F7-B887592DCDB1B16E (Accessed: 9 July 2020) 